\title{
The Natural Resource Base and Industrialization in Asia -In assessing phenomenal deforestation and industrialization of Thailand-
}

\author{
Tatsuo Sweda*1, Kitti Limskul*2, Seizo Hotta*3, \\ Adisorn Noochdumrong**4 and Emmanuel Rhodantes G. Abraham*5
}

\begin{abstract}
In pre-industrial societies, forests provide most daily necessities, ranging from fuelwood to construction material and from supplementary food to fertilizer. Forest resources become even more important as the firsthand source of energy and materials for both industrial and household uses when the society tries to industrialize itself, thus making the availability of forest resources one of the key factors for successful industrialization. In this paper, the present endowment of forest resources in the countries of South and Southeast Asia is analyzed in a historical and geophysical perspective so as to assess their potential for industrialization from a natural resources point of view, with a special emphasis on Thailand. Though at the heavy cost of deforestation, Thailand seems to have been one of the successful forerunners in the post-World War II Asian effort of industrialization, and its experience in the ordeal of deforestation and associated socioeconomic conflict should provide a good lesson for the rest of the countries in the region.
\end{abstract}

Keyword: natural resource base, industrialization, civilization center, peripheral region, hinterland region

\section{INTRODUCTION}

Deforestation in tropical and sub-tropical countries has been one of the major issues of global concern for the past few decades. The warning evoked by the Club of Rome (MeAdows et al. 1972, MEsarovic and PESTE 1974) against unchecked economic growth at the expense of natural resources, both renewable and non-renewable, may be the one of the earliest, while this view has since been strengthened and more widely acknowledged by such succeeding reports as those from the U.S. Presidential Committee

*1 Department of Biological Resources and Environment, Nagoya University, Chikusa, Nagoya 464-01 Japan

*2 Socio-Economic Policy and Forecasting Unit, Chulalongkorn University, Phayathai Road, Bangkok 10500 Thailand

*3 Nagoya Economics University, Uchikubo, Inuyama 484 Japan

${ }^{* 4}$ Royal Forest Department, Bangkhen, Bangkok 19000 Thailand

*5 Department of Biological Resources and Environment, Nagoya University, Chikusa, Nagoya 464-01 Japan
(BARNEY 1980a, 1980b, 1980c), FAO (LANLY 1982) etc..

The rise of a civilization and the accociated increase in human population have always been made possible at the expense of forests since ancient times. Even discounting the climate changes that have occurred since the days of ancient civilizations, the shrubby and denuded lands of Central China, Indus Valley, Hindustan Plains, Mesopotamia and Egypt, all tell of the long-lasting impacts of the great ancient civilizations. The same is true of the modern civilization of European countries. It was wood as fuel, and as building, industrial and shipbuilding material that enabled the early industrial renovations of the 16th and 17th Centuries to occur, which in turn nursed the real industrial revolution to come (NEF 1932), as well as the subsequent continuation and rise of modern Western civilization. As a result, the forests that predominantly covered European countries shrank to the present coverage of some 30 percent or less of the total land area.

Of course, forest resources can not be exploited for nothing. Deforestation causes a wide variety of problems. It starts with such very localized problems as the loss of fertile topsoil and landslides in the limited area where deforestation took place, but its consequences expand 
downstream in the form of silting, flooding, shortage and irregularity of water supply etc. This has been true in ancient as well as in modern civilizations.

The industrialized nations of today, which include most of Europe, North America and some countries in the Pacific Basin have also suffered from these problems in their respective course of industrialization in the relatively recent past. However, in view of the developing countries of the tropical and sub-tropical regions today, the already industrialized nations were happy since their difficulties and responsibilities were limited to the more-or-less localized problems mentioned above. In other words, even when their forests were depleted and exhausted at home, innumerable forests were still remeining in the other regions of the globe from where raw woody materials could be extracted in exchange for industrial products as did the British from North America for ship-building material throughout the 18th and 19th centuries (JAMES 1981), and Japan from Southeast Asia for industrial wood in its recovery from the exhaustive defeat in World War II (WWII).

Furthermore, the already-industrialized nations were happy in that the innumerable forests in other regions of the globe than the land of their own held down such global environmental problems as climate change for which current global deforestation is considered to be part of the cause by altering the global albedo and depleting the carbon dioxide reservoir (Bolin et al. 1986).

In this regard, the currently developing countries in the tropics and subtropics which are in desperate need of forest resources as fuel, industrial material, fertilizer and so on in their efforts to industrialize, are triply burdened, i.e. the exploitation of their own forests evokes not only resource shortages and evnironmental problems at home, but also grave danger to the global environment.

The long-range objective of our work is to find narrow pathways for the industrialization of developing countries through these labyrinth of problems that the exploitation of forest resources cause, locally, nationally and internationally. The reason Asia and Thailand were chosen above others, was that they are respectively the region and the country in which the rate of deforestation has been most pronounced in association with economic development, and therefore, the conflict between the forest exploitation and the resultant socioeconomic problems are considered to be the most pronounced, intensive and telltale of the rest of the developing world. In this paper, the present state of the Asian forests is discussed in a broad historical perspective to identify where Thailand and its forests stand in the geographical/historical frame of the region, followed by an examination of Thailand's socioeconomic problems resulting from the deforestation and degradation of its forests.

\section{FORESTS OF ASIA}

Effects of Ancient Civilizations upon the Forests of Asia

From the ancient civilization point of view, Asia east of Pakistan, can be classified into three categories, i.e. the central region of major civilizations, the peripheral region to those major civilizations, and the hinterland region that stretches behind the peripheral region. Although these bounds of the ancient civilizations and the boundaries between the present political units do not necessarily coincide, the central region of civilizations undoubetedly includes China and India. The second region may include such countries as Thailand, Korea, Viet Nam, etc., which lie directly neighboring the centers. The third region, which may includes Japan, Indonesia, Malaysia, etc., were doubly segregated from the direct influence of the central civilizations by the peripheral countries of the second group, as well as by the surrounding seas.

Although they have been obscured to a certain extent by the influence of more recent civilizations brought to Asia along with such successive religious philosophies as Hinduism, Moslem, Catholicism and then Protestantism to a varying degree depending on the country involved, the effects of these ancient civilization are still strongly felt in the present status of forests.

In a way, human civilization can be defined as a complex of technological, political and social systems which enables more human population to be supported in a more luxurious way. Thus, the establishment of a civilization means the establishment of technological, political and social systems which exploit natural resources more effectively than before. Until the late phase of industrial revolution, when considerable bioresources were replaced by mineral resources as the source of energy and raw materials, the former, originating almost exclusively from forests, was the major source of energy and material to support civilizations. The iron output from charcoal-burning smelters was surpassed by that from coke smelters so late as the 1790's even in Great Britain (NEF 1932).

Thus it is no wonder that in the region where ancient civilizations flourished and were subsequently passed down over thousands of years, the lands and forests had been exhausted and depleted long before the arrival of modern civilization by supporting a huge mass of population almost continuously to the point where today, any further exploitation is almost impossible.

In the region of the other extreme, i.e. in the hinterland region of the ancient civilizations, both forests and land fertility have been very well preserved until recently due to the scarce population for forests to support. Even after the massive extraction of timber by modern means of heavy machinery in the last couple of decades, in order to 
meet post-WWII industrial demands as well as to support rapidly increasing local population, the thick and lush forest cover of this region is no comparison with the impoverished shrubby forests of the ancient civilization centers.

In the peripheral regions, the history and present status of demography and forests are just midway between the above two extremes. In this region, local civilizations such as Sukhotai (ca. 1230-1440), Ayuthaya (ca. 1350-1770), and Chakri (1782-present) Dynasties of Thailand, Pagan (ca. 1040-1330) and Toungu (ca. 1500-1750) Dynasties of Burma, and so on, flourished under the direct or indirect influences of, and on-and-off contact with the major civilizations of China or India or both. Being younger, smaller, less-lasting and thus less populous than the major ones, these local civilizations exploited land and forests less intensively and extensively than did the major civilizations. As a result, the forests of this region have been better preserved than those of the civilization centers, but not as well as those of the hinterland region. The effects of the ancient and medieval civilizations upon forests discussed above, are shown schematically in Fig. 1.

Interestingly enough, the above classification of countries by the distance from the ancient civilization centers, roughly corresponds with the natural geographical zoning of Asia by continentality or oceanicity. The region of the central civilizations is situated right in the continental part of Asia, while much of the peripheral region consists of countries in coastal Asia, and the hinterland region covers most of insular and peninsular Asia. In view of this correspondence, the terms "civilization centers", "peripheral regions" and "hinterland" are used henceforth interchangeably with the terms "continental", "coastal" and "insular/peninsular" Asia.

Before closing this section, it would be fair to note that another important factor that makes the civilization centers less forested than the peripheral region, which in turn is less forested than the hinterland, is their difference

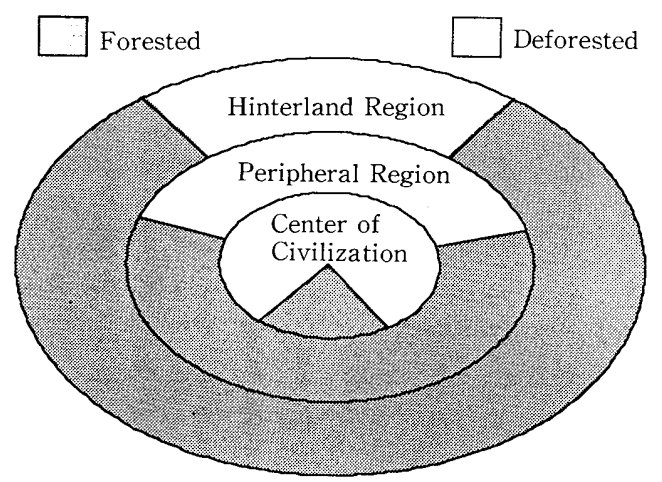

Fig. 1 Effects of ancient and medieval civilization upon present forest cover in continentality, or conversely oceanicity. The ocean is the very source of precipitation which is essential to tree growth and formation of forests. Thus, being surrounded by the sea, insular/peninsular Asia is more naturally endowed than coastal Asia, and much more so than continental Asia in terms of potential for tree growth and forest cover as well as for recovery of vegetation from devastation.

\section{Present State of Forests of South-Southeast Asia}

To provide the above discussion with some statistical evidence, and to show the state of Thai forests in comparison with those of neighboring nations as well, forest cover statistics for 16 nations in South and Southeast Asia are given in Tables 1 through 3. For statistical consistency, all the original data in the Tables was derived from the Tropical Forest Resources Assessment Project of the United Nations' Food and Agriculture Organization (FAO 1981). As the name of the original data source indicates, the countries involved are exclusively from South and Southeast Asia. Tables 1 and 2 respectively, show estimates of natural woody vegetation at the end of 1980 and 1985, while Table 3 shows the difference between them, i.e. the trend of deforestation and forest degradation in the five years.

In accordance with the notion of remoteness from the great ancient civilizations, the 16 countries involved were classified into three groups, i.e. civilization center (CC), peripheral region $(\mathrm{PF})$ and hinterland region (HL). Most of the countries involved can be easily classified. There is not much room to debate in classifying India as civilization center, Thailand as peripheral and Papua New Guinea as hinterland, whereas a few of them, like countries such as Nepal and Lao, may need more rigorous historical and cultural examination before their classification is firmly established. For the present analysis, however, the tentative classification given in Table 1 through 3 should suffice.

The original FAO data is far more complicated, with the natural woody vegetation being classified into great detail by such multiple of criteria as species composition, stand density, production capacity, management status, past logging history etc., but they were aggregated here so that each given breakdown would stand out to a reasonable degree by itself. By the same token, fallow area which was originally given for each vegetation type, is also put together under the column heading "Fallows", so as to include all those resulting from harvesting of all forms of closed and open forests.

As has been mentioned in the preceding section, the most striking difference between the three regions is the existing forested area. In 1980 (Table 1), natural woody vegetation covers only about 20 percent on average, of the total land area in the countries of the civilization center, whereas it covers 60 percent in the peripheral region and 80 percent in the hinterland region. Similarly, closed forests 
Table 1 Area of natural woody vegetation at the end of 1980 as estimated by FAO (in thousand ha)

\begin{tabular}{|c|c|c|c|c|c|c|c|c|c|c|c|c|c|}
\hline \multirow{5}{*}{$\begin{array}{l}\text { Classi- } \\
\text { fica- } \\
\text { tion }\end{array}$} & \multirow{5}{*}{ Country } & \multirow{5}{*}{$\begin{array}{l}\text { Total } \\
\text { Land } \\
\text { Area }\end{array}$} & $\mathrm{N} \quad \mathrm{a}$ & $\mathrm{u}$ & $\mathrm{a}$ & $\mathrm{W}$ & o & $\mathrm{d}$ & $\mathrm{V}$ & e & e & $\mathrm{a}$ & $\mathrm{o} \mathrm{n}$ \\
\hline & & & \multirow[t]{4}{*}{ Tọtal } & $\mathrm{T}$ & $\mathrm{r}$ & $\mathrm{e}$ & $\mathrm{F}$ & 0 & $\mathrm{~m}$ & $\mathrm{t}$ & $\begin{array}{ll}\mathrm{i} & \mathrm{o}\end{array}$ & $\mathrm{n}$ & \multirow[t]{4}{*}{ Shrub } \\
\hline & & & & \multirow[t]{3}{*}{ Total } & $\mathrm{C}$ & o & $\mathrm{e}$ & $\mathrm{F}$ & $\mathrm{e}$ & $\frac{\mathrm{s}}{\mathrm{Bam}-}$ & \multirow{3}{*}{$\begin{array}{l}\text { Open } \\
\text { Forest }\end{array}$} & \multirow[t]{3}{*}{ Fallows } & \\
\hline & & & & & \multirow[t]{2}{*}{ Total } & \multicolumn{3}{|c|}{ Broadleave } & \multirow{2}{*}{$\begin{array}{l}\text { Coni- } \\
\text { fer }\end{array}$} & \multirow{2}{*}{$\begin{array}{l}\text { Bam- } \\
\text { boo }\end{array}$} & & & \\
\hline & & & & & & Total & Prod'v & Unprod. & & & & & \\
\hline $\mathrm{CC}$ & Nepal & 14,080 & 2,461 & 2,231 & 2,051 & 1,61 & 1.055 & 555 & 330 & 1 & 180 & 110 & 230 \\
\hline $\mathrm{CC}$ & Pakistan & 80,394 & 3,585 & 2,480 & 2,185 & 86 & 220 & 640 & 1,325 & 0 & 295 & 0 & 1,105 \\
\hline $\mathrm{CC}$ & India & 328,759 & 72,082 & 66,704 & 61,311 & 46,04 & 38,358 & 7,686 & 4,357 & 1,440 & 5,393 & 9,470 & 5,378 \\
\hline $\mathrm{CC}$ & Bangladesh & 14,400 & 1,242 & 1,242 & 1,242 & 92 & 850 & 77 & 0 & 0 & 0 & 315 & 0 \\
\hline $\mathrm{HL}$ & P. New Guinea & 46,169 & 39,705 & 39,620 & 35,610 & 33,710 & 14,035 & 19,675 & 520 & 0 & 4,010 & 1,445 & 85 \\
\hline $\mathrm{HL}$ & Philippines & 30,000 & 13,030 & 13,030 & 13,030 & 9,320 & 6,700 & 2,620 & 190 & 0 & 0 & 3,520 & 0 \\
\hline $\mathrm{HL}$ & Malaysia & 32,975 & 25,820 & 25,820 & 25,820 & 20,99 & 15,552 & 5,443 & 0 & 0 & 0 & $0 \quad 4,825$ & 0 \\
\hline $\mathrm{HL}$ & Indonesia & 190,435 & 158,155 & 134,255 & 127,355 & 113,57 & 73,575 & 40,000 & 320 & 0 & 6,900 & 17,360 & 23,900 \\
\hline $\mathrm{HL}$ & Brunei & 577 & 560 & 560 & 560 & 32 & 287 & 36 & 0 & 0 & 0 & 237 & 0 \\
\hline $\mathrm{PF}$ & & 18,104 & 13,273 & 12,873 & 7,748 & 7,15 & 5,120 & 2,030 & 18 & 380 & 5,125 & 225 & 400 \\
\hline $\mathrm{PF}$ & Thailand & 51,400 & 16,975 & 16,475 & 10,035 & 8,13 & 3,915 & 4,220 & 200 & 900 & 6,440 & 800 & 500 \\
\hline $\mathrm{PF}$ & Lao & 23,680 & 19,360 & 18,625 & 13,410 & 7,56 & 2,880 & 4,680 & 250 & 600 & 5,215 & 5,000 & 735 \\
\hline $\mathrm{PF}$ & $\mathrm{Bl}$ & 4,700 & 2,370 & 2,345 & 2,305 & 1,49 & 1,315 & 175 & 610 & 0 & 40 & 205 & 25 \\
\hline $\mathrm{PF}$ & Sri Lanka & 6,561 & 2,727 & 2,512 & 2,512 & 1,65 & 1,226 & 433 & 0 & 0 & 0 & 853 & 215 \\
\hline PF & Viet Nam & 32,956 & 21,190 & 20,860 & 19,520 & 7,40 & 3,670 & 3,730 & 170 & 1,200 & 1,340 & 10,750 & 330 \\
\hline $\mathrm{PF}$ & Burma & 67,655 & 52,641 & 50,041 & 50,041 & 31,19 & 23,116 & 8,077 & 116 & 632 & & 18,100 & 2,600 \\
\hline & Total & 942,843 & 445,176 & 409,673 & 374,735 & 291,95 & 191,874 & 100,077 & 8,406 & 5,153 & 34,938 & 37,215 & 35,503 \\
\hline Civili & ation & 437,633 & 79,370 & 72,657 & 66,789 & 49,44 & 40,483 & 8,958 & 6,012 & 1,441 & 5,868 & 39,895 & $5 \quad 6,713$ \\
\hline Perip & eral & 205,055 & 128,536 & 123,731 & 105,571 & $64,58^{\prime}$ & $7 \quad 41,242$ & 23,345 & 1,364 & 3,712 & 18,160 & 35,933 & 34,805 \\
\hline Hinter & land & 300,155 & 237,270 & 213,285 & 202,375 & 177,92 & 110,149 & 67,774 & 1,030 & 0 & 10,910 & 27,387 & 23,985 \\
\hline
\end{tabular}

Table 2 Area of natural woody vegetation at the end of 1985 as estimated by FAO (in thousand ha)

\begin{tabular}{|c|c|c|c|c|c|c|c|c|c|c|c|c|c|}
\hline \multirow{5}{*}{$\begin{array}{l}\text { Classi- } \\
\text { fica- } \\
\text { tion }\end{array}$} & \multirow{5}{*}{ Country } & \multirow{5}{*}{$\begin{array}{l}\text { Total } \\
\text { Land } \\
\text { Area }\end{array}$} & $\mathrm{N} \quad \mathrm{a}$ & $\mathrm{u}$ & a 1 & $\mathrm{~W}$ & o & $\mathrm{d}$ & $\mathrm{V}$ & e $g$ & t & $\mathrm{t}$ & $\begin{array}{lll}i & o & n \\
\end{array}$ \\
\hline & & & Total & $\mathrm{T}$ & $\mathrm{r}$ & $\mathrm{e}$ & $\mathrm{F}$ & 0 & $\mathrm{~m}$ & $\mathrm{t}$ & 0 & $\mathrm{n}$ & \multirow[t]{4}{*}{ Shrub } \\
\hline & & & & Total & C 1 & s & d & o & $\mathrm{e}$ & $\mathrm{t}$ & \multirow{3}{*}{$\begin{array}{l}\text { Open } \\
\text { Forest }\end{array}$} & \multirow{3}{*}{ Fallows } & \\
\hline & & & & & \multirow[t]{2}{*}{ Total } & \multicolumn{3}{|c|}{ Broadleave } & & \multirow{2}{*}{$\begin{array}{l}\text { Bam- } \\
\text { boo }\end{array}$} & & & \\
\hline & & & & & & Total & Prod'v & Unprod. & fer & & & & \\
\hline $\mathrm{CC}$ & Nepal & 14,080 & 2,046 & 1,816 & 1,636 & 1,210 & 730 & 480 & 310 & 1 & 180 & 115 & 230 \\
\hline $\mathrm{CC}$ & Pakistan & 80,394 & 3,860 & 2,435 & 2,150 & 855 & 215 & 640 & 1,295 & 0 & 285 & 0 & 1,425 \\
\hline $\mathrm{CC}$ & India & 328,759 & 72,531 & 67,153 & 61,760 & 45,384 & 37,758 & 7,626 & 4,302 & 1,420 & 5,393 & 10,654 & 5,378 \\
\hline $\mathrm{CC}$ & Bangladesh & 14,400 & 1,227 & 1,227 & 1,227 & 887 & 825 & 62 & 0 & 0 & 0 & 340 & 0 \\
\hline $\mathrm{HL}$ & P. New Guinea & 4,617 & 39,595 & 39,510 & 35,500 & 33,600 & 13,920 & 19,680 & 520 & 0 & 4,010 & 450 & 85 \\
\hline $\mathrm{HL}$ & Philippines & 30,000 & 11,570 & 11,570 & 11,570 & 8,865 & 6,250 & 2,615 & 185 & 0 & 0 & 2,520 & 0 \\
\hline $\mathrm{HL}$ & Malaysia & 32,975 & 25,191 & 25,191 & 25,191 & 19,721 & 14,378 & 5,343 & 0 & 0 & 0 & 5,470 & 0 \\
\hline $\mathrm{HL}$ & Indonesia & 190,435 & 157,160 & 133,260 & 126,3601 & 110,580 & 67,540 & 43,040 & 320 & 0 & 6,900 & 19,460 & 23,900 \\
\hline $\mathrm{HL}$ & Brunei & 577 & 560 & 560 & 560 & 298 & 262 & 36 & 0 & 0 & 0 & 262 & 0 \\
\hline $\mathrm{PF}$ & Kampucea & 18,104 & 13,203 & 12,788 & 7,683 & 7,025 & 5,005 & 2,020 & 18 & 380 & 5,105 & 290 & 415 \\
\hline PF & Thailand &, 400 & 15,280 & 14,780 & 8,975 & 6,915 & 2,880 & 4,035 & 195 & 865 & 5,805 & 1,000 & 500 \\
\hline $\mathrm{PF}$ & $\mathrm{Lac}$ & 23,680 & 19,085 & 13,310 & 7,060 & 2,455 & 4,605 & 250 & 600 & 5,040 & 5,400 & 735 & \\
\hline $\mathrm{PF}$ & Bhutan & 4,700 & 2,360 & 2,335 & 2,295 & 1,485 & 1,310 & 175 & 605 & 0 & 40 & 205 & 25 \\
\hline $\mathrm{PF}$ & Sri Lanka & 6,561 & 2,371 & 2,156 & 2,156 & 1,368 & 1,000 & 368 & 0 & 0 & 0 & 788 & 215 \\
\hline $\mathrm{PF}$ & et Nam & 32,956 & 21,415 & 21,085 & 19,745 & 7,100 & 3,470 & 3,630 & 145 & 1,200 & 1,340 & 11,300 & 330 \\
\hline \multirow[t]{2}{*}{$\mathrm{PF}$} & Bruma & 67,655 & 52,590 & 49,990 & 30,685 & 22,608 & 8,077 & 113 & 617 & & 18,575 & 2,600 & \\
\hline & Total & 901,291 & 440,044 & 404,206 & 370,1082 & 283,038 & 180,606 & 102,432 & 8,258 & 5,083 & 34,098 & 77,829 & 35,838 \\
\hline \multicolumn{2}{|c|}{ Civilization } & 437,633 & 79,664 & 72,631 & 66,773 & 48,336 & 39,528 & 8,808 & 5,907 & 1,421 & 5,858 & 11,109 & 7,033 \\
\hline \multirow{2}{*}{\multicolumn{2}{|c|}{$\begin{array}{l}\text { Peripheral } \\
\text { Hinterland }\end{array}$}} & 205,055 & 126,304 & 121,484 & 104,154 & 61,638 & 38,728 & 22,910 & 1,326 & 3,662 & 17,330 & 37,558 & 4,820 \\
\hline & & 258,603 & 234,076 & 210,091 & 199,1811 & 173,064 & 102,350 & 70,714 & 1,025 & 0 & 10,910 & 29,162 & 23,985 \\
\hline
\end{tabular}


Table 3 Deforestation and degradation of natural woody vegetation between 1980-1985 (in thousand ha)

\begin{tabular}{|c|c|c|c|c|c|c|c|c|c|c|c|c|c|}
\hline \multirow{5}{*}{$\begin{array}{l}\text { Classi- } \\
\text { fica- } \\
\text { tion }\end{array}$} & \multirow{5}{*}{ Country } & \multirow{5}{*}{$\begin{array}{l}\text { Total } \\
\text { Land } \\
\text { Area }\end{array}$} & \multirow{2}{*}{$\begin{array}{l}N \text { a } t \\
\text { Total }\end{array}$} & \multirow{2}{*}{$\frac{\mathrm{u} r}{\mathrm{~T}}$} & a 1 & W & o & $\mathrm{y}$ & $\mathrm{V}$ & e $g$ & $\mathrm{t}$ & $a t$ & $\begin{array}{lll}i & o & n \\
\end{array}$ \\
\hline & & & & & $\mathrm{r}$ & $\mathrm{e}$ & $\mathrm{F}$ & $\mathrm{r}$ & $\mathrm{m}$ & $\mathrm{a} \quad \mathrm{t}$ & $\mathrm{i}$ & $\mathrm{n}$ & \multirow[t]{4}{*}{ Shrub } \\
\hline & & & & \multirow[t]{3}{*}{ Total } & C 1 & o & $\mathrm{d}$ & $\mathrm{F}$ & $\mathrm{e}$ & $\frac{\mathrm{t}}{\text { Bam- }}$ & \multirow{3}{*}{\multicolumn{2}{|c|}{$\begin{array}{l}\text { Open Fallows } \\
\text { Forest }\end{array}$}} & \\
\hline & & & & & \multirow[t]{2}{*}{ Total } & \multicolumn{3}{|c|}{ Broadleave } & \multirow{2}{*}{\multicolumn{2}{|c|}{$\begin{array}{ll}\text { Coni- } & \text { Bam- } \\
\text { fer } & \text { boo } \\
\end{array}$}} & & & \\
\hline & & & & & & Total & Prod'v & Unprod. & & & & & \\
\hline $\mathrm{CC}$ & Nepal & 14,080 & 415 & 415 & 415 & 400 & 325 & 75 & 20 & 0 & 0 & -5 & 0 \\
\hline $\mathrm{CC}$ & Pakistan & 80,394 & -275 & 45 & 35 & 5 & 5 & 0 & 30 & 0 & 10 & 0 & -320 \\
\hline $\mathrm{CC}$ & India & 328,759 & -449 & -449 & -449 & 660 & 600 & 60 & 55 & 20 & & $-1,184$ & 0 \\
\hline $\mathrm{CC}$ & Bangladesh & 14,400 & 15 & 15 & 15 & 40 & 25 & 15 & 0 & 0 & 0 & -25 & 0 \\
\hline $\mathrm{HL}$ & P. New Guinea & 4,617 & 110 & 110 & 110 & 110 & 115 & -5 & 0 & 0 & 0 & -5 & 0 \\
\hline $\mathrm{HL}$ & Philippines & 30,000 & 1,460 & 1,460 & 1,460 & 455 & 5 & 5 & 0 & 0 & 1,000 & 0 & \\
\hline $\mathrm{HL}$ & Malaysia & 32,975 & 629 & 629 & 629 & 1,274 & 1,174 & 100 & 0 & 0 & 0 & -645 & 0 \\
\hline $\mathrm{HL}$ & Indonesia & 190,435 & 995 & 995 & 995 & 2,995 & 6,035 & $-3,040$ & 0 & 0 & & $-2,100$ & 0 \\
\hline $\mathrm{HL}$ & Brunei & 577 & 0 & 0 & 0 & 25 & 25 & 0 & 0 & 0 & 0 & -25 & 0 \\
\hline $\mathrm{PF}$ & Kampucea & 18,104 & 70 & 85 & 65 & 125 & 115 & 10 & 0 & 0 & 20 & -65 & -15 \\
\hline PF & Thailand & 51,400 & 1,695 & 1,695 & 1,060 & 1,220 & 1,035 & 185 & 5 & 35 & 635 & -200 & 0 \\
\hline PF & Lao & 23,680 & 275 & 275 & 100 & 500 & 425 & 75 & 0 & 0 & 175 & -400 & 0 \\
\hline$P F$ & Bhutan & 4,700 & 10 & 10 & 10 & 5 & 5 & 0 & 5 & 0 & 0 & 0 & 0 \\
\hline PF & Sri Lanka & 6,561 & 356 & 356 & 356 & 291 & 226 & 65 & 0 & 0 & 0 & 65 & 0 \\
\hline $\mathrm{PF}$ & Veit Nam & 32,956 & -225 & -225 & -225 & 300 & 200 & 100 & 25 & 0 & 0 & -550 & 0 \\
\hline \multirow[t]{2}{*}{$\mathrm{PF}$} & Burma & 67,655 & 51 & 51 & 51 & 508 & 508 & 0 & 3 & 15 & 0 & -475 & 0 \\
\hline & Total & 901,291 & 5,132 & 5,467 & 4,627 & 8,913 & 11,268 & $-2,355$ & 148 & 70 & 840 & $-4,614$ & -335 \\
\hline \multirow{3}{*}{\multicolumn{2}{|c|}{$\begin{array}{l}\text { Civilization } \\
\text { Peripheral } \\
\text { Hinterland }\end{array}$}} & 437,633 & -294 & 26 & 16 & 1,105 & 955 & 150 & 105 & 20 & 10 & $-1,214$ & -320 \\
\hline & & 205,055 & 2,232 & 2,247 & 1,417 & 2,949 & 2,514 & 435 & 38 & 50 & 830 & $-1,625$ & -15 \\
\hline & & 258,603 & 3,194 & 3,194 & 3,194 & 4,859 & 7,799 & $-2,940$ & 5 & 0 & 0 & $-1,775$ & 0 \\
\hline
\end{tabular}

cover 15,50 and 70 percent of the respective total land area. There is no doubt that this marked difference between the three regions is a reflection of differences in the duration of human activities since the days of ancient civilizations.

Another marked contrast between the three regions is the rate of deforestation (Table 3). While the area of natural woody vegetation disappeared by a couple of million of hectares in the peripheral and hinterland regions during the five years, it even increased (negative signs) in the region of ancient civilization centers. This means that with the area of natural woody vegetation at less than one fifth of the total land area, there is virtually no forest left to be exploited in the latter region.

\section{Regional Characteristics}

(1) Region of ancient civilizations

As has been mentioned above the characteristic of the region of ancient civilization is the naked scarcity of the remaining natural woody vegetation to such an extreme as to make any further exploitation virtually impossible, even where there is desperate need of wood as fuel and industrial material. Even at this extreme of scarcity, the area of natural woody vegetation varies by country, ranging from 4.46 percent of the total land area in Pakistan to 21.93 percent in India. There is no doubt that in addition to population pressure, dry continental climate makes it more difficult for depleted forests to recover in Pakistan, but equally scarce natural woody vegetation (8.63 percent) in Bangladesh, where more than enough moisture is provided by heavy monsoon rain and two great rivers originating in the Himalayas, tells the magnitude of population pressure in this region in general.

The use of animal dung, widely practiced throughout South Asian countries as a domestic source of energy for cooking and other daily needs of heat, indicates that forests of this region had long been in a similar state of depletion even prior to the explosive population growth after WWII. To make matters worse, the increased demand for energy and raw materials resulting primarily from this increase in population, has also been directed to forests due to a chronic lack of foreign currency to buy alternative energy sources and raw materials from abroad.

This remains the same today. Although the area of natural woody vegetation, as a whole, is increasing (negative values in Table 3 ), the deterioration in forest inventory is still continuing, as indicated by the decrease in highlystocked closed broadleaved forests and the corresponding increase in the area of much more poorly stocked fallows and shrubs.

(2) Hinterland region

From the historical point of view, exactly the oppo- 
site explanation holds for the forests of the hinterland region, i.e. the less population to be supported means much forest preserved. Thus from a vegetation point of view, the thick and lush forests of this region are no comparison to the exhausted shrubby forests of continental Asia. From an industrial timber resources point of view, however, a considerable part of these insular and peninsular forests has been depleted.

Due to the relatively rich forest resources still remaining, forests are most rapidly exploited volume-wise in this region at present, mainly for industrial timber, and subsequently by shifting cultivation. Areas of virgin forests logged-over annually and areas of secondary forests subjected to second logging, are also greatest in this region. However, relatively abundant forest resources, relatively intact soil fertility and lower population pressure in this region combine to prevent logging to result directly in deforestation.

In this region too, differences exist between the countries, and they are greater than between the countries of the ancient civilization centers. While natural woody vegetation covers nearly 80 percent or more of the total land area in Papua New Guinea, Malaysia, Indonesia and Brunei, it is only slightly more than 40 percent in the Philippines. This may be explained partly by the relatively early penetration of the country by modern Western civilization, which is more productive and thus more destructive than the traditional Oriental civilization, and partly by the extensive and intensive logging operations after WWII, mainly for export to Japan.

\section{(3) Peripheral region}

In this region as a whole, the natural woody vegetation accounts for slightly less than 50 percent of the land area, a coverage well below that of the hinterland region, but significantly better than that of the civilization centers. The younger and more modest local civilizations of this region had demanded less sacrifice, and thus, although forests had been exploited, forest deterioration was neither as intensive nor extensive as it was in the major civilization centers.

In comparison with the other regions, the countries of this region are much more differentiated from each other in such aspects as degree of political and military disturbance after WWII, political system, geographical location and cultural strain. These differences show themselves in the area of natural woody vegetation, which is highest in Lao at 82 percent of the total land area, and lowest in Thailand at 33 percent. Generally, the forests are better preserved in the countries involved in military disturbances after WWII, than in the countries relatively free from them. Interestingly enough, the latter nations are much better off economically than the former.

This fact indicates the significant dependence of economic development upon forest resources. The difference in the percentage of forested area between the warplagued and war-free countries, may thus be taken as an indication of the toll that economic growth placed on the latter in the last 40 years or so following WWII. This difference, amounting to some 30 percent of the given land area on average, might look like too much for the cost of 40 years of economic build-up, but it should be remenbered that the post-WWII means of forest harvesting is much more effective, and thus destructive, than its prewar counterparts. Another important factor responsible for the rapid deforestation, is the relatively unthrifty habit of forest exploitation in this region. Due to the relative abundance of forest resources in the past, the people of this region failed to developed a thrifty culture to cope with limited forest resources as did the direct descendants of the major civilizations. As a consequence of all these factors combined, the forests of the region, which were already at a certain level of exhaustion, are easily giving way as we see today.

\section{FACTORS AFFECTING DEFORESTATION IN THAILAND}

\section{Overview}

It has already been shown that with forest cover at only one third of the nation's land, Thailand is the least forested nation in the peripheral region. Fig. 2, compiled from Table 3, shows that it is also the nation with the highest rate of deforestation. In no other country of the entire region under consideration, are forests disappearing at such a staggering rate of over 300,000 ha annually. As has been suggested earlier, this rapid rate of deforestation coincides very well with the rapid rate of economic growth of Thailand. The postwar gross domestic production (GDP) of the country expanded at a mean annual rate of

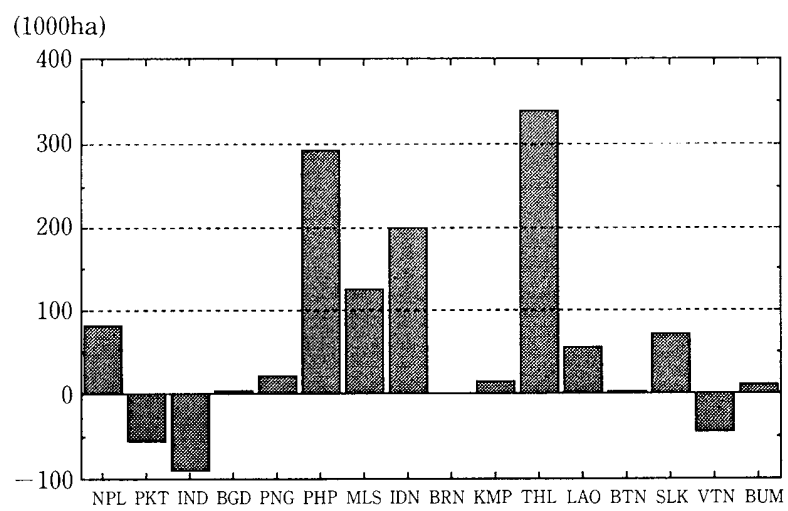

Fig. 2 Annual rate of deforestation by country 
seven percent by the late $1980 \mathrm{~s}$. Discounting the somewhat dampened growth in this decade, the mean growth by the beginning of the ' 80 s was even higher.

This parallelism between deforestation and economic growth not only indicates the heavy dependence of economic development upon the availability of forest resources, but also reminds us of RICHARDSON's (1966) remark on forest and economic development in China. Shortly after WWII, when the best bet for economic and social development was considered to be China and India by the majority of observers, Richardson, on his invited trip to China, showed an opposite view, reasoning that the exhausted forests of China wouldn't match its expected growth. The Thailand case gives another proof to Richardson's far-sighted inference.

Besides economic growth, there are many other factors responsible for the rapid postwar deforestation in Thailand either directly by themselves or indirectly through contribution to economic growth. The important factors and the relationship between them are shown in
Fig. 3. The three most basic factors that eventually affect the rate of deforestation are the country's long period of peace since the late 18 th Century, the sustained independence throughout the times of colonialism and imperialism of the 19th and 20th centuries, and the climate. The first two factors are interdependent, and the way they contribute to deforestation through economic growth and other factors has already been discussed in general terms in the preceding section.

The climatic control of vegetation and deforestation is mainly through precipitation. Precipitation in Thailand is not distributed evenly throughout the year, but concentrated in the monsoon months of June through September. During the monsoon, prevailing southwesterlies bring moist air from the Andaman Sea, but the country is parched for the rest of the year by the dry northeasterlies from Central Asia and the strong solar radiation of subtropics. What makes the country drier is the Bilauktaung Range which, stretching along the Burmese border on the west, puts much of Thailand, including the most populous Chao

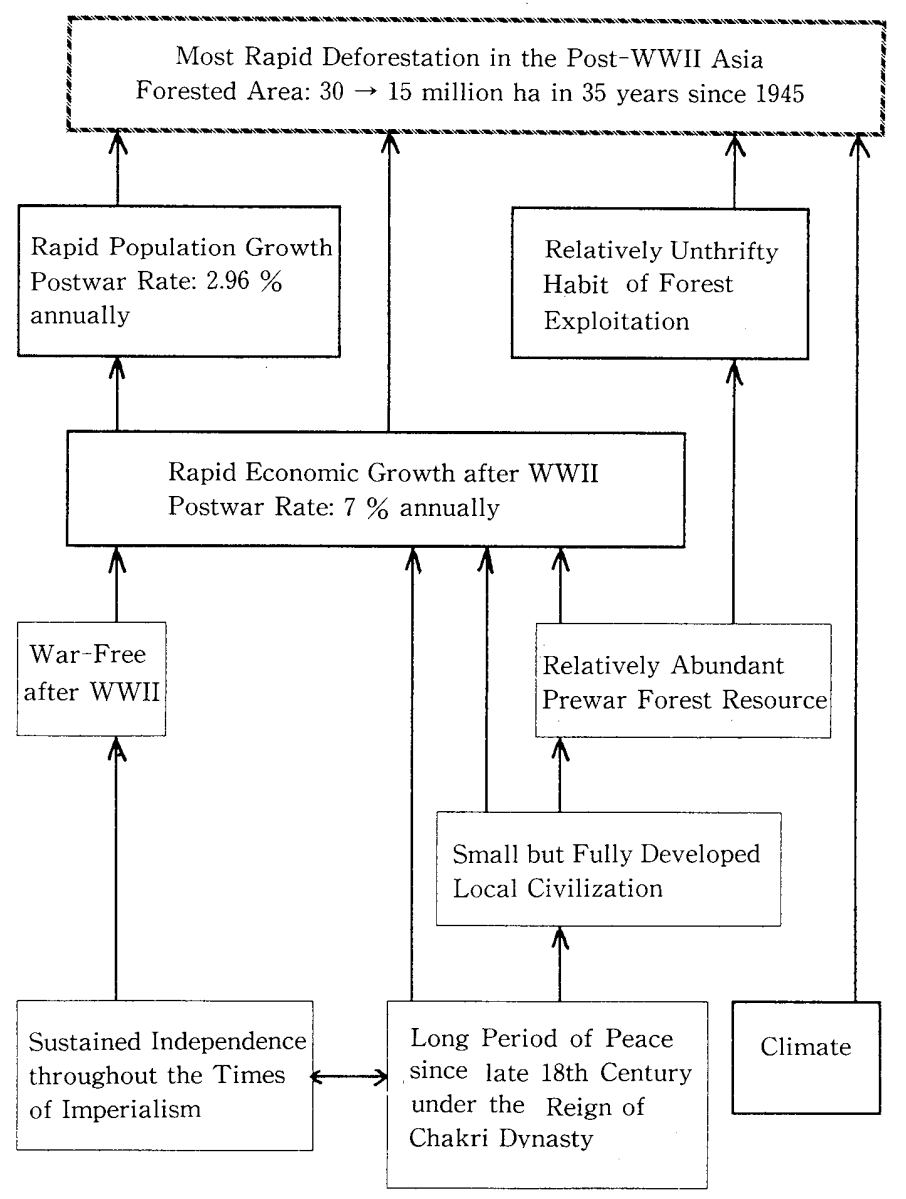

Fig. 3 Significant factors and their relationship leading to rapid deforestation in the postwar Thailand 
Phraya Basin and the large Northeast Region, in the rain shadow of the moist southwesterlies. Thus, except for the southern peninsular part of the country, dry teak and dipterocarpus forests predominate, which are relatively vulnerable to exploitation and difficult to return once exploited.

Of the four factors which are directly associated with deforestation in Fig. 3, climate is beyond human control, thus, the measures against deforestation should be taken on the rest of the factors. Although either way doesn't look straightforward, as discussed in the next section, what makes the future bright is the discovery of natural gas in the Gulf of Siam in 1973 and the beginning of production in 1983. The shift of industrial and domestic sources of energy from fuel wood and charcoal to natural gas, will certainly ease the burden on the forests.

\section{Socioeconomic Problems Evoked by Deforestation}

Along the same line as what has been mentioned above, the rapid deforestation in the northern and northeastern part of the country has been continually observed since the end of WWII. On the one hand, logging industries partly financed the development of other light industries during 1960-1975, through earning from export of teak and other wood products in various forms. On the other hand, logging industries were both the push-and-pull factors towards deforestation. The push factor, led by the people in the industry themselves, was shown in the form of extraction of wood from once natural forests, while the pull factor was shown in the form of agricultural plantation and opening up of new cultivated land by rural-rural migration stemming mainly from economic factors. The latter was further aggravated by the habit of shifting cultivation by the minority tribes in the north and along the Laos and Burmese borders. One realizes immediately that Thailand has reached the deforestation frontier once he travels along the border of northeast Thailand and Laos.

Unlike the north, where teaks were such precious wood to be eagerly exploited, in the northeast, scant leftover timber of lesser market value in the paddy field (mostly glutinous rice and cultivated once in a year) were enormously cut down during the last decade. This rapid rate of depletion came after the deforestation had come nearer to the frontier in the 1980's.

The socioeconomic consequences of the country-wide deforestation came in the forms of drought and flood, and from time to time resulted in insufficient rice stock even for self-consumption in the northeast. Many northeast villages fell below the poverty level of the country. This caused rural-urban migrations, especially to Bangkok. Sussangkan (1987) estimates that approximately 60 percent of rural labor (roughly 2.4 million workers) are potential migrants actively seeking jobs. A considerable number of farm workers remaining in the agriculture sector are those who are not able to migrate due to a lack of skills and education.

In the north, where cultivating areas were insufficient relative to the population pressure, the socioeconomic conflicts came in different forms. For example disputes between timber profiteers vis-a-vis villagers over the source of the water supply for agriculture.

In the south, the timber industry was a late comer as compared with the other regions. Interestingly enough, logging occurred when the deforestation reached nearer to its frontier. It seems that deforestation was moving southward. The rapid rate of depletion resulted in a striking flood during the rainy season of 1988 .

The disaster brought about by this flood may be regarded as the sequential peak of the deforestation in Thailand. The government (the Ministry of Agriculture and Cooperatives) initiated an indefinite prohibition on logging. The public at large seemed to have approved of this proposal. We should regard this public reaction as a sign of "recognition of the deforestation frontier" in Thailand. The demand for timber by the logging and wood product industries is presently met by import from Malaysia, Burma, Cambodia and Lao. The price of wood and wood products has returned to the normal market level.

The central region where the center of economic growth is located, still remains the country's most valuable rice bowl. It should be noted here that the Chao Praya River and its four major tributaries, namely the Ping, Wang, Yom and Nan, were the crucial routes down which logs were transported to the central region for domestic consumption and export.

While the government is obviously the most responsible for failing to protect natural forests, trespassers are sometimes blamed as the main culprit of deforestation. An eviction plan has been undertaken from time to time. Yet at present it is estimated that there are about 1.5 million families or nearly 10 million people living illegally in the forest reserve area. However, the government can not find places for them to move to and earn a living. One of the possible solutions is to grant them land rights and let them be the caretakers of forests i.e., legislation of the community forest.

Some scholar dated the existence of the community forest back to the Sukothai Dynasty of over 700 years ago. Others have argued that the existing community forests in many regions of the country give proof that villagers are competent forest managers. For instance in Huay Donsai village of the northern province of Lampoon, villagers have taken care of the community forest for generations. As a matter of fact, the community forest has expanded from 60 rai (1rai $=0.16 \mathrm{ha}) 70$ years ago, to more than 1600 rai at present. For a comparison, a research study showed that 
one forestry official has to look after about 30,000 rai of forest area with a budget of 3 Baht per rai for conservation (1U.S.\$ = approx. 26 Bahts).

One of the major targets of the Sixth Economic and Social Development Plan is to bring the forest area back to 40 percent of the country's total land area (it was 66 percent in 1950 and 28 percent or even less in 1989) comprising 15 percent for conservation area and 25 percent for production. The 25 percent is mostly in the hands of private owners who are likely to plant such fast-growing trees as Eucalyptus for paper and furniture industries in degraded forest areas. They are given a 30 year concession in the forest reserve land at the price of 10 Baht per rai per year.

The socioeconomic impact of the deforestation in Thailand is not limited within its borders, but has an international dimension of both cost and benefit. The total logging ban in Thailand will benefit the ecological system of the country, but at the cost of forest depletion in Burma, Lao and perhaps Sarawak, since the thirsty demand for lumber in Thailand must be fulfilled in one way or another. In view of the sacrifice of humanity resulting from the loss of forests, as well as the cost of recovering them in the long run, the present market price of timber seems too low. The decision of whether or not to cut a forest is not a national matter anymore, but a matter of optimum management of a limited global asset.

\section{LITERATURE CITED}

Barney, Gerald O., (1980a): The Global 2000 Report to the President of the U.S., Entering the 21st Century Volume I: The Summary Report. Pergamon Press, New York, vxii+360pp.

Barney, Gerald O., (1980b): The Global 2000 Report to the President of the U.S., Entering the 21st Century Volume II: The Technical Report. Pergamon Press, New York, xxxvi+766pp.

BARney, Gerald O., (1980c): The Global 2000 Report to the President of the U.S., Entering the 21st Century Voume III: The Government' s Global Model. Pergamon Press, New York, ix +401pp.

Bolin, G., Doos, B.R. JAger, J. and WArRICK, R.A., (1986): The Greenhouse Effect, Climate Change and Ecosystems. SCOPE 29. J. Wiley and Sons, New York, 541pp.

Chulalongkorn University Social Research Institute, (1986): Forestry Development Project under the Fifth National Economic and Social Development Plan (1982-1986), Executive Summary. Chulalongkorn University, Bangkok, 47pp.

FAO, (1981): Forest Resources of Tropical Asia. FAO, Rome, ix +475 pp.

James, N.D.G., (1981): A History of English Forestry. Basil Blackwells, Oxford, xii $+339 \mathrm{pp}$.

LANLy, Jean-Paul, (1982): Tropical Forest Resources. FAO, Rome, $\mathrm{xii}+106 \mathrm{pp}$.

Meadows, D.H., Meadows, D.L., Randers, J. and Behrens III, W.W., (1972): The Limits to Growth. The first report of the club of Rome. Potamac Associates, Washington, D.C.

Mesarovic, M. and Peste, E., (1974): Mankind at the Turning Point. The second report of the Club of Rome. E.P. Dutton-Reader's Digest Press, New York.

Nef J.U., (1932): The Rise of the British Coal Industry, Vol. I. George Routledge and Sons, London, xiv $+448 \mathrm{pp}$.

Richardson, (S.D., 1966): Forestry in Communist China. Johns Hopkins University Press, Baltimore.

(Received 22 May 1995)

(Accepted 30 June 1995) 